\title{
Editorial
}

\section{The Toronto Conference}

The Fifth International Congress on Mental Health which met in Toronto in August this year was in some ways the most ambitious and comprehensive yet held. For this, praise must go both to the Executive Board and officers of the World Federation for Mental Health and also to the local organising committee whose programme was a masterpiece of intricate and interdependent arrangements which would have done Bradshaw no discredit.

Delegates from all six continents spoke on the platform at the opening session and even if, as was natural, there was a preponderance of members from the North American continent, there were contingents from 50-odd countries, including for example, Australia, Ceylon, the Sudan and the U.S.S.R. Opportunities for informal discussion of the various problems of mental health in these countries were frequently available and eagerly taken, and these can have done nothing but good.

An important feature of this Congress was the preliminary series of working parties (more formally designated "Research Symposia") held on three different topics-the development of the child, the relation between public health and mental health, and the application of psychiatry to industry. To each had been invited a group of members from abroad who were faced with the need for presenting their findings to the main conference when it later assembled. Their work was thorough but slow and if anyone had expected to find the panacea for all ills in any of these three fields, he must have gone away disappointed. The results in the three groups had curious similarities. More information was needed, it was commonly agreed, and there was much discussion on the methods by which research could be carried out. In this the first task to be attempted was the integration of the various workers in the field; many disciplines were represented (as many, or more, no doubt as are represented by the readers of this journal) and their representatives furnished evidence from their own experience-and sometimes in their own behaviour at the discussions-of misunderstandings, prejudices and even personal animosities which can bedevil understanding and co-operation. It was noticeable that these were more intense between members of different disciplines than between members of different nationalities, or even races, which lends hope- - even if Science does not yet always cross interracial gaps or inter-ideological curtains - that a comparable training and common interest may go some way towards doing so. As an interesting sidelight on this was the episode when an English 
psychiatrist was able to understand a Russian comment on schizophrenia and explain it to the (lay) Russian interpreter. Besides this, real progress was made in the description of developments in thought and technique in different countries, in subjects as widely apart at first sight, as infant welfare and governmental responsibility.

The plenary sessions were packed and the rest of the day was spent in technical sections or Round Table discussions on set topics, or in small informal working parties meeting to discuss any topic that occurred. The only trouble was that it was impossible to attend them all.

Inevitably there was some mental indigestion afterwards and even those who had a sea voyage home, have probably not yet fully recovered. The danger is that we all find so many urgent-but not necessarily important-things to do that we slip back to our hard working but unthinking routine and forget the lessons learned as a remedy to this. It may be useful to keep in our minds the ways in which we can co-operate in mental hygiene with those of other disciplines and the need to understand their attitudes, aims and difficulties.

We see around us people so limited by their mental filing systems that they miss or are hurt by most of their experience, whilst others grow and profit by everything that happens to them. We need not be surprised; the human organism would be strange indeed if any form of organisation were as useful as any other. We would expect, for example, even if every mental hospital were not full of evidence to prove it, that complete self-centredness would be a most inconvenient organising principle for creatures such as we are.

Seen from this angle by far the most significant discovery of mental science is the power of love to protect and to restore the mind. Every filmgoer, every newspaper reader today, believes that there is likely to be a causal relationship between the deprived child and the adolescent criminal. He will accept on the authority of science, that love can build for one child a haven of security in a mad world and can thus equip it to give back the same powerful influence in after life, whilst its absence may leave another imprisoned in self and capable of no contact with its kind but aggression. It is not of ten that the findings of science confirm the intuitions of religion in language which does not even need to be translated. This alone, in my view, entitles mental science to be regarded not as a rival but as a partner in the eternal effort to realise spiritual values in the daily life of men and women-even perhaps in the policies of Governments.

From Paper on "Mental Health and Spiritual Values" given by Sir Geoffey Vickers at Toronto, August 1954. 